\title{
Extracting useful data from imperfect monitoring schemes: endangered butterflies at San Bruno Mountain, San Mateo County, California (1982-2000) and implications for habitat management
}

\author{
Travis Longcore $\cdot$ Christine S. Lam • \\ Patrick Kobernus $\cdot$ Eben Polk $\cdot$ John P. Wilson
}

Received: 29 April 2009/Accepted: 7 January 2010/Published online: 20 January 2010

(C) The Author(s) 2010. This article is published with open access at Springerlink.com

\begin{abstract}
Managers surveyed for sensitive butterfly species in the San Bruno Mountain Habitat Conservation Plan area between 1982 and 2000 using an opportunistic "wandering transect" method. To extract as much valuable information as possible from the data collected by this method we analyzed patterns of surveys and butterfly presence and absence within $250 \mathrm{~m}$ square cells gridded across the area within a Geographic Information System. While estimates of butterfly abundance were not possible, the data could be tested for trends in butterfly occupancy. For those cells surveyed during at least 10 years, no trends in the total number of occupied cells was evident for either Callippe silverspot or mission blue butterfly. There were cells, however, that showed positive or negative trends $(P<0.20)$ in occupancy for each species (Callippe silverspot: 14 positive, 15 negative, 6 cells occupied all years; mission blue butterfly: 40 positive, 40 negative, 2 cells occupied all years). We conclude that for the period 19822000 the population of each species was stable in overall total distribution, but indicate geographic areas of concern for each, specifically the edges of the northeast ridge for Callippe silverspot butterfly and the northwest of the study area for mission blue butterfly. Vegetation composition analysis using orthophotography with field corroboration
\end{abstract}

T. Longcore $(\bowtie) \cdot$ C. S. Lam · J. P. Wilson

Department of Geography, University of Southern California,

Los Angeles, CA 90089-0255, USA

e-mail: longcore@usc.edu; longcore@urbanwildlands.org

P. Kobernus

Coast Range Ecology, San Francisco, CA 94112, USA

E. Polk

Clackamas County Office of Sustainability, Oregon City, OR 97045, USA indicates that those areas with declines in occupancy for these species experienced native coastal scrub succession and a corresponding loss in grassland butterfly habitat, while positive trending and stable cells had stable grassland proportions. Habitat managers at San Bruno Mountain should therefore incorporate programs for protecting grassland butterfly habitat not only from invasive weeds but also from succession to native coastal scrub. This approach illustrates the feasibility of using occupancy as an indicator to track butterfly status in a protected area even when suboptimal data collection methods are used, but the difficulties of using these data also reinforces the need for managers to devise monitoring schemes appropriate for their objectives before implementing them.

Keywords Monitoring · Endangered species ·

Succession $\cdot$ Lepidoptera

The Habitat Conservation Plan (HCP) at San Bruno Mountain just south of San Francisco, California was, in 1982, the first of its kind, opening a pathway for a new type of conservation mechanism wherein loss of habitat for species listed under the Endangered Species Act is permitted in exchange for conservation actions to benefit the species (Beatley 1994). Approximately $80 \%$ of the mountain has been conserved as open space through land purchases, donations and exchanges, and is managed as habitat for listed butterflies through the HCP. As part of the management of the reserve established at San Bruno Mountain, yearly surveys were conducted to count listed butterfly species and butterfly species of regulatory concern (Thomas Reid Associates 2000). The surveys have been digitized and compiled in a Geographic Information System (ArcGIS), which facilitates in-depth analysis of the 
status and trends of populations of these sensitive species. This article presents the results of an analysis of these data and an assessment of the survey methodology.

The surveys at San Bruno Mountain record incidence of two species, mission blue butterfly (Icaricia icarioides missionensis) and Callippe silverspot butterfly (Speyeria callippe callippe). A third species, San Bruno elfin (Incisalia mossii bayensis), was surveyed but is not addressed here. The surveys, called "Wandering Surveys" by Thomas Reid Associates ("TRA"), followed no fixed route and were conducted throughout the flight seasons of both species from 1982 to 2000 . The rationale for using the wandering transect methodology was to monitor as much of the butterflies' habitat as possible at the least cost, and to allow monitors flexibility to cover different habitat areas as conditions change over time for the purposes of informing and directing habitat management. Such a methodology presents immediate difficulties for drawing statistical inference or even detecting qualitative trends. The goal of our analysis is to extract useful information from the dataset, while acknowledging the flaws inherent in the survey methods.

Several challenges are posed by the analysis of the San Bruno Mountain butterfly data. Some can be solved, some are likely intractable. The first problem posed by the dataset is that surveys were not completed in the same geographic locations each year. Most butterfly monitoring schemes involve repeated, fixed transects (Pollard et al. 1975; Pollard and Yates 1993; van Swaay et al. 2008). In this manner, the number of individuals each year can be compared with some degree of confidence. The second problem is that the data provide no obvious way to estimate what proportion of butterflies is being observed each year. Detection probability is a central part of monitoring schemes; for butterflies it can be calculated either from mark-recapture data (Gall 1985) or distance sampling (Buckland et al. 1993). In our analysis, neither option is available. Detection probability is affected by the use of different survey locations each year that may have different habitat features that increase or decrease detection, or detection probability may vary by sex, time of day, or weather (Dennis et al. 2006a; Dennis and Sparks 2006; Harker and Shreeve 2008). Because of these two difficulties with estimating butterfly abundance, we chose rather to investigate trends in the distribution of the species, which although still sensitive to variation in detection should be somewhat less sensitive to it than are abundance estimates.

Knowledge of trends in the geographic distribution of the butterflies on San Bruno Mountain is in some ways superior to knowledge of trends in abundance. Butterflies are notoriously variable in abundance from year to year and wide fluctuations may obscure directional trends (Pollard 1988). Occupancy (or at least observation) and abundance are related: butterflies will be detected in more locations in years when butterflies are abundant if only because the chances of encountering a butterfly are increased (Zonneveld et al. 2003). Aside from this apparent increase in occupancy resulting from greater population size, some patches may indeed be colonized during years with many adult butterflies. In either instance, if butterflies are observed in more areas it is a good sign for the species. Indeed, mathematical models of metapopulation persistence often record only the number and occupancy rate of habitat patches, not the number of butterflies at each patch (Hanski 1999), and occupancy of more locations is associated with decreased risk of extinction (Schultz and Hammond 2003).

The research questions therefore involve the distribution patterns of mission blue butterfly and Callippe silverspot 1982-2000.

- Has each species exhibited directional trends in total area occupied?

- What areas have exhibited directional trends in occupancy?

- What areas have exhibited large and small variability in occupancy?

A second set of research questions address the survey methodology.

- What areas exhibited trends in survey coverage?

- What areas were surveyed frequently and infrequently?

- What was the relationship between survey frequency and occupancy?

\section{Study system and life history}

San Bruno Mountain is a 1395-ha state and county park located $1 \mathrm{~km}$ south of San Francisco, California (Fig. 1). Elevation ranges from 20 to $400.5 \mathrm{~m}$. The mountain's western boundary is $4 \mathrm{~km}$ east of the Pacific Ocean and the eastern boundary is less than $1 \mathrm{~km}$ from San Francisco Bay. Average annual rainfall is $56 \mathrm{~cm}$ per year. Marine air flow consisting of strong westerly winds and summertime fog strongly influences the distribution of plant communities on San Bruno Mountain, and the vegetation is dominated by northern coastal scrub and grassland. Woodland vegetation (coast live oak woodland and central coast riparian scrub) is primarily limited to narrow ravines. Invasive plant communities are also present, with the densest stands located on the northern edge of the study area.

The mission blue butterfly is univoltine and has a flight period that extends from March to mid-June. Three perennial lupines (Lupinus albifrons var. collinus, L. formosus var. formosus, and $L$. variicolor) are larval host 


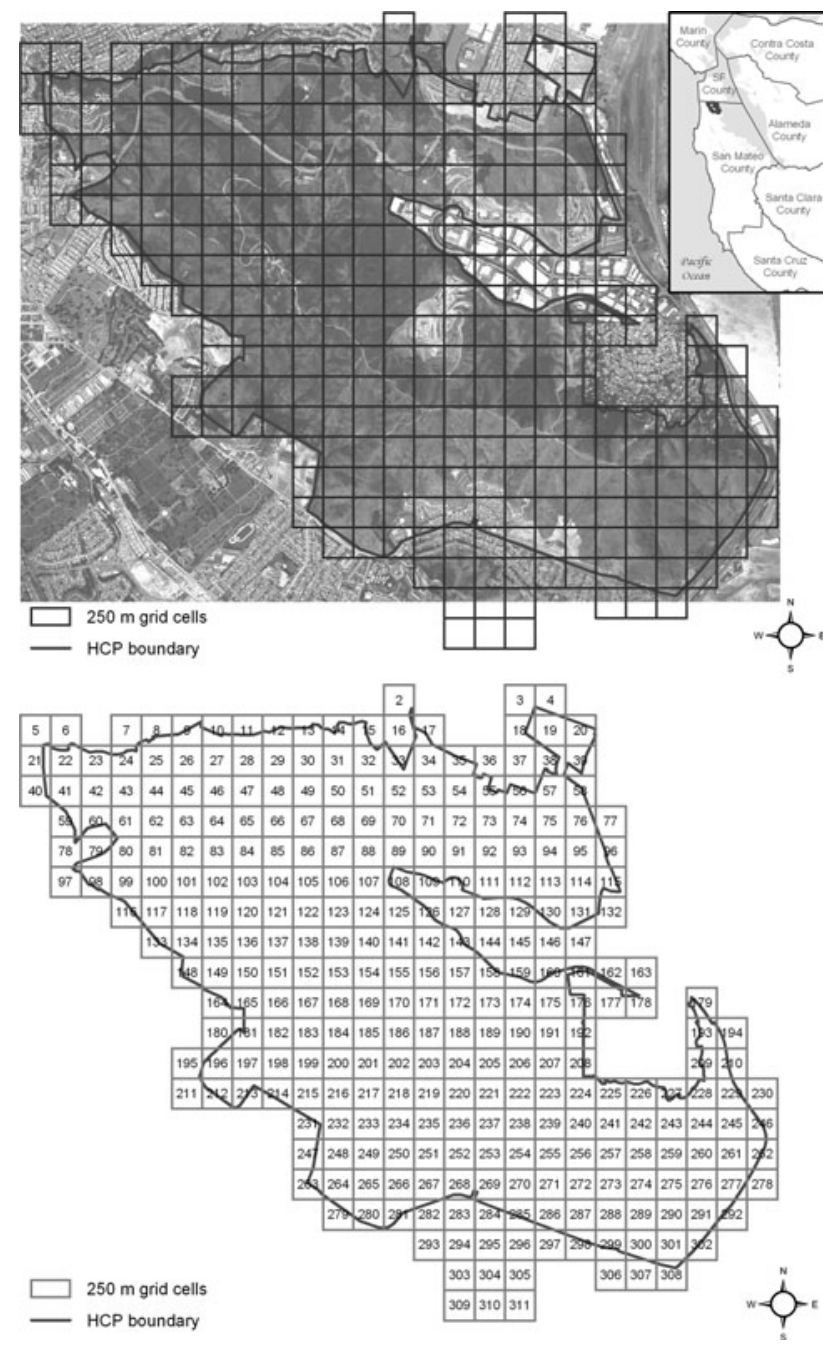

Fig. 1 Top aerial photograph and location of San Bruno Mountain HCP. Bottom numbered grid for analysis of butterfly survey data

plants for the species. Throughout their flight period, the females lay their eggs on the host plants soon after mating. Single eggs are deposited primarily on the leaves, but also the stems, flowers, and seedpods of the host plants. The eggs hatch in about 4-10 days (Downey 1957; Guppy and Shepard 2001). The first and second instar larvae feed on the mesophyll of the hostplants. About 3 weeks after eclosion the second instar larvae begin an obligate diapause, typically at the base of the foodplants. The following spring the larvae break diapause and resume feeding. The last instar larvae pupate on or near the base of the Lupinus foodplant (Arnold 1983). The pupal stage lasts approximately 3 weeks (Guppy and Shepard 2001). Markrecapture data showed that the majority of movements by adult butterflies are $<64 \mathrm{~m}$, with males moving on average slightly more than females (Arnold 1983). Maximum observed movement was on the order of $150 \mathrm{~m}$ for both sexes (Arnold 1983).
The Callippe silverspot is univoltine and has a flight period that generally extends from mid-May to mid-July (Arnold 1981). Callippe silverspot larvae consume one host plant, Viola pedunculata, a perennial forb that typically grows in high densities within grassland habitats where it is present. During the early summer flight season, the adult females lay their eggs in the vicinity of Viola pedunculata, but not on it (Mattoon et al. 1971). Larvae hatch from the eggs in about a week (Arnold 1981). After hatching, larvae eat the lining of the eggshell, take shelter in ground litter, and then enter diapause (Arnold 1981; Mattoon et al. 1971). Most Callippe silverspot larvae remain in diapause from early summer until the following spring, but some briefly interrupt diapause by seeking shelter from adverse conditions during this period, followed by a return to diapause (Mattoon et al. 1971). After diapause, Callippe silverspot larvae begin feeding on the leaves of their foodplant and develop through five instars (Arnold 1981). After the fifth instar, larvae enter the pupal stage, which lasts about 2 weeks (Arnold 1981). Callippe silverspots are strong fliers, as is the genus as a whole. Mark-recapture data show movement of individuals between two colonies at San Bruno Mountain, over $1 \mathrm{~km}$ distant (Thomas Reid Associates 1982a). Most individuals fly within an area that is $1.2 \mathrm{~km}$ across at San Bruno Mountain, only 5-6\% of individuals were found at a distance greater than this from the site of first capture (Thomas Reid Associates 1982a). On average adults of a related silverspot species move $68.6 \mathrm{~m} /$ day, but some individuals move up to $1.6-1.8 \mathrm{~km}$ (Nagal et al. 1991; Ricketts 2001).

The mission blue butterfly's distribution on San Bruno Mountain is closely tied to the distribution of its host plants and is most frequently encountered flying over or resting on or within a few feet of its host plants. All three host plants are patchily distributed within grasslands, rocky outcrops and disturbed areas (roadcuts, landslides, hiking trails). The Callippe silverspot's larval host plant, Viola pedunculata, is also found in grasslands and disturbed habitats. Hostplants for both species are not present in topographic swales or ravines with deeper soils and wetter conditions, or in areas that have dense stands of invasive weeds, dense stands of native scrub or woodlands. Both species overlap in distribution considerably. The mission blue is more widespread, however, occurring in open grasslands and isolated hilltops and roadcuts on the east and west side of the Mountain, whereas the Callippe silverspot is largely restricted to the more extensive grasslands on the east side of San Bruno Mountain. The Callippe silverspot is a hilltopping species, and frequently is encountered in high densities on hilltops adjacent to open grassland slopes with Viola pedunculata and preferred nectar plants. Both mission blue and the Callippe silverspot nectar at a wide variety of native and nonnative forbs 
(Arnold 1981; Thomas Reid Associates 1982a). The mission blue and Callippe silverspot butterflies populations on San Bruno Mountain are demographically isolated by the surrounding cities.

\section{Methodology}

Thomas Reid Associates (now TRA Environmental Sciences) conducted butterfly surveys in the San Bruno Mountain HCP area (Fig. 1) every year between 1982 and 2000. Prior to this, the distribution and habitat preferences of both the mission blue butterfly and the Callippe silverspot were identified and mapped on the entire HCP area, and the populations of both species were estimated using mark and recapture techniques during the 1980-1981 flight seasons (Thomas Reid Associates 1982a).

The 1982-2000 surveys were characterized as "wandering" transects, because the observers did not follow any set route but rather conducted surveys across the mountain and recorded survey routes and locations of any butterflies observed. Timing of surveys and weather conditions were also recorded. Surveys were conducted through the adult flight season of both butterfly species. Results from these surveys were digitized by TRA and are managed in a Geographic Information System.

To analyze the butterfly survey data, we overlaid a $250 \mathrm{~m}$ square grid over the San Bruno Mountain HCP area (Fig. 1). The grid size provides a sufficient number of cells to identify differences across the study area but not so many that analysis is intractable. Furthermore, each grid cell is sufficiently large to incorporate the elements necessary for butterfly reproduction, including foodplants, nectar sources, and potentially ridgelines for hilltopping.

For each $250 \mathrm{~m}$ square cell and for each year for each species, the number of visits, total length of surveys, and presence of the butterfly was recorded. For this analysis, we considered that a cell was "surveyed" if at least $250 \mathrm{~m}$ of surveys were conducted within the cell during a particular year. This constitutes a substantial assumption, because detection of butterflies depends on the number, length, and timing of surveys (Zonneveld et al. 2003). The risk of choosing $250 \mathrm{~m}$ as a cut-off is that some cells where the butterfly was actually present will be recorded as absences because (1) too few surveys were conducted to detect a small population, (2) surveys were timed improperly to detect adults, or (3) the butterfly was too cryptic to detect because of behavioral or weather conditions. While such false negatives are possible, false positives are not, at least in the sense that the butterflies are in an area, except for the instance of the misidentification of an adult butterfly. This will lead to a very conservative analysis because it considers butterflies present in a cell even if the individual is a vagrant that is not using any resources. The cumulative result of such an approach is a bias that may overestimate occupancy (Dennis 2001). That is, we are measuring presence of each species without necessarily establishing "occupancy" in the manner of studies that connect butterflies to their essential resources (Dennis et al. 2003, 2006b). Summary statistics such as the number of years each cell was surveyed and the proportion of years butterflies were observed were also recorded.

For each cell and each butterfly, we completed a logistic regression of occupancy with year as the independent variable. Trends with $P<0.20$ were recorded. This relatively low confidence threshold serves to provide a conservative analysis that can identify potential areas of change in the distribution of each species. If a requirement to meet a higher significance level is required, then greater confidence can be achieved but the opportunity for remediation would be delayed. To investigate the spatial pattern of these trends we calculated the ratio of positive to negative trends in the 9-cell neighborhood surrounding each cell with a positive or negative trend, hypothesizing that in a metapopulation positive and negative trends would be clustered.

Callippe silverspots are a hilltopping species so one would expect that males would have been more frequently observed on ridge tops (Shields 1967). We analyzed the use of ridgelines by both species to test this hypothesis. Ridgelines were identified by querying a $10-\mathrm{m}$ digital elevation model (DEM) to assign a rank to each cell relative to all other cells within a $30 \mathrm{~m}$ circular radius, using the ElevResidGrid algorithm (written by John Gallant, CSIRO Land and Water). The ranking ranges from 0 (lowest cell within $30 \mathrm{~m}$ ) to 1 (highest grid cell). The DEM was clipped at the HCP boundary to avoid interference from the urban topography surrounding it. Ridgelines were identified as those cells with a ranking of 0.66 and higher. A higher value (e.g., 0.75) would present few sparse grid cells across the study area to identify contiguous ridgelines. A lower value (e.g., 0.60) would classify an excessive number of cells as ridgelines, including cells that were predominantly hillslopes. We then mapped a $25 \mathrm{~m}$ buffer around ridgeline cells and recorded the number of butterflies of each sex found within the buffer area. For comparison, we recorded the same data for mission blue butterfly, which Arnold (1983) had considered to hilltop for mate location, but later decided it was found on hilltops because of food resources and was not a true hilltopping species.

For each cell identified with a significant change in butterfly occupancy, changes in land use and vegetation were investigated using vegetation maps, terrestrial and aerial imagery, and orthophotography of San Bruno Mountain for the period between 1982 and 2004. Land use 
and vegetation changes observed for each cell were then corroborated in the field.

\section{Results}

During the 19 years of surveys, 295 of 310 cells were surveyed at least one time (Fig. 2). Some cells were surveyed significantly less frequently over time. The number of cells surveyed that did not support either endangered butterfly decreased significantly over time, as did the total length of survey routes per year (Fig. 3). This change in survey distribution indicates that surveyors directed efforts in locations where butterflies had been found before, and avoided areas that had yielded negative results for a number of years. While some cells were surveyed for many

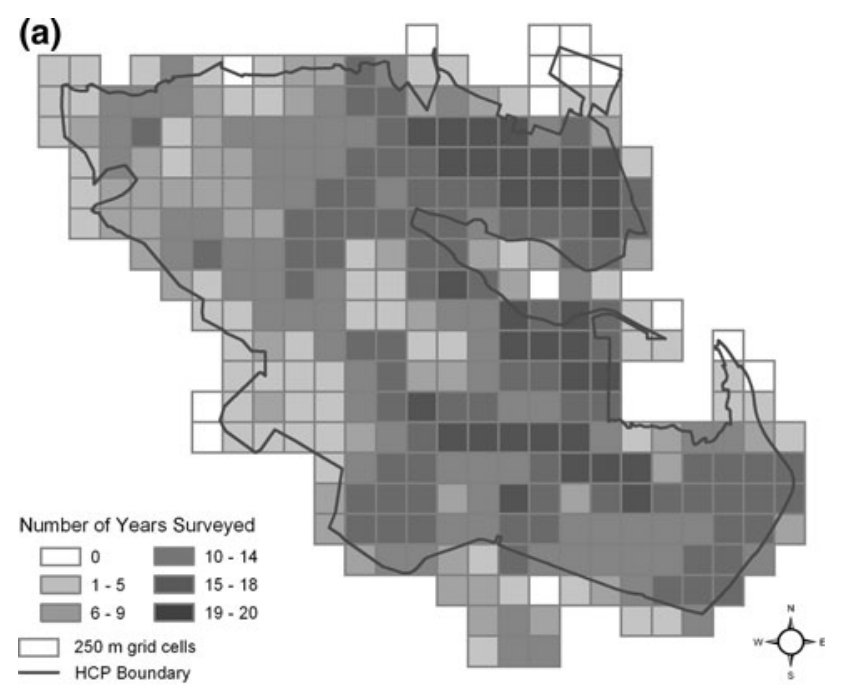

(b)

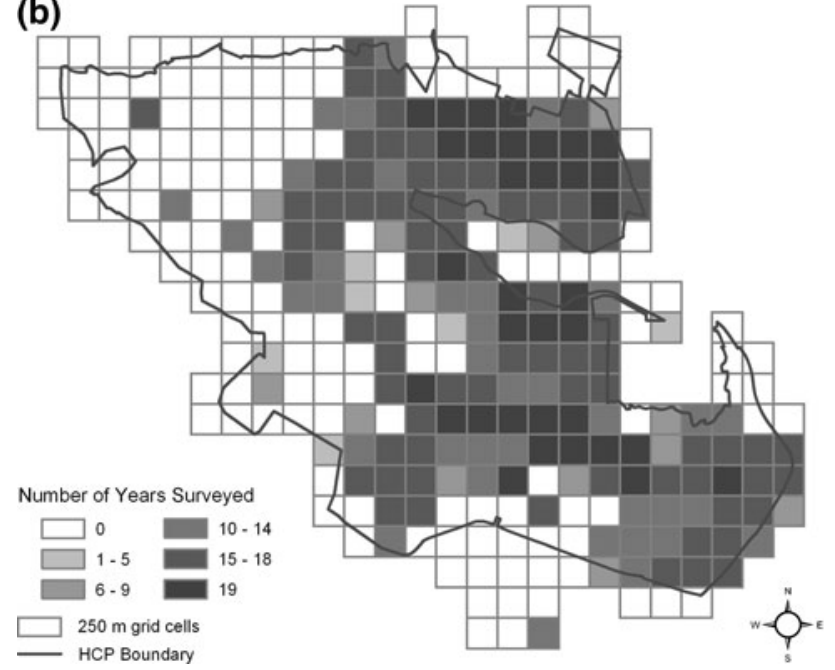

Fig. 2 Distribution and frequency of surveys for mission blue butterfly (a) and Callippe silverspot butterfly (b) at San Bruno Mountain, 1982-2000 years $(>15)$ with no butterflies of either species found, they were located along routes to sites that support the target species.

Survey distribution for mission blue butterfly and Callippe silverspot both show a concentration in the northeast ridge and along other ridge-tops where access is less difficult (Fig. 4). The western side of the HCP area has been surveyed somewhat less than the eastern regions, reflecting, among other things, the climatic preferences of the butterflies (Weiss and Murphy 1990) and the scarcity of the butterflies' host plants on the west side of the mountain.

The tendency over time was for the surveyors to stop searching for the butterflies in areas that had been surveyed with negative results several times. Consequently, the number of "empty" cells surveyed decreases significantly during the study period (Fig. 3a). This was accompanied by a significant overall decrease in the total length of surveys each year (Fig. 3b).

The changing effort and location of surveys each year violates the assumptions of random sampling and uniform methodology. Several of the metrics that might be used to track population status therefore reveal instead artifacts of the methodology. For example, the average number of Callippe silverspots observed per meter of transect appears to show a positive trend over time (Fig. 3c). This trend is spurious, because surveys over time concentrated increasingly on cells where butterflies were present, even though some presumably unsuitable habitat was surveyed en route to grassland areas. Without surveying marginal habitats with butterflies absent, the apparent density of butterflies increases. All such butterflies per meter estimates derived from these data are similarly uninformative in evaluating population status because they are not comparable year to year. Similarly, the raw proportion of cells occupied by either butterfly is a spurious measure because of the decreasing number of "absent" cells surveyed over time (Fig. 3d). Therefore, while the proportion of cells with Callippe silverspot present each year increased significantly, the absolute number of occupied cells showed no statistical trend (Fig. 3e). But the absolute number of occupied cells is also misleading, because of the decreasing number of total cells surveyed over time. Therefore the best measure of trends in occupancy involves analysis of the proportion of cells occupied, when limited to those cells where the species was observed at least once. For these cells with at least one observation, neither butterfly shows a significant trend in the number of cells occupied over time (Fig. 3f).

Given that no overall trends in the proportion of the range occupied by either species exist for the study period, the analysis concentrates on trends within individual cells over time. The limits of such trend analysis extend to the 218 cells that were occupied at least once by mission blue 
Fig. 3 Characteristics of surveys for Callippe silverspot butterfly. a Number of cells surveyed per year where species was not detected with linear regression. b Total survey length per year with linear regression. $\mathbf{c}$ Number of butterflies observed per meter of transect-a spurious measure of population status because transect location and effort were not fixed. d Proportion of cells occupied each year-also influenced by changing survey effort. e Total number of cells with butterfly present per year. f Proportion of cells occupied of those cells where butterfly was located at least once during any year. The horizontal line indicates the mean $(47 \%)$ (a)

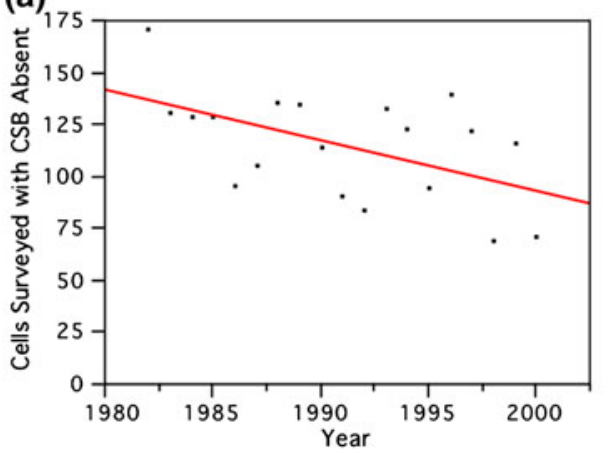

(b)
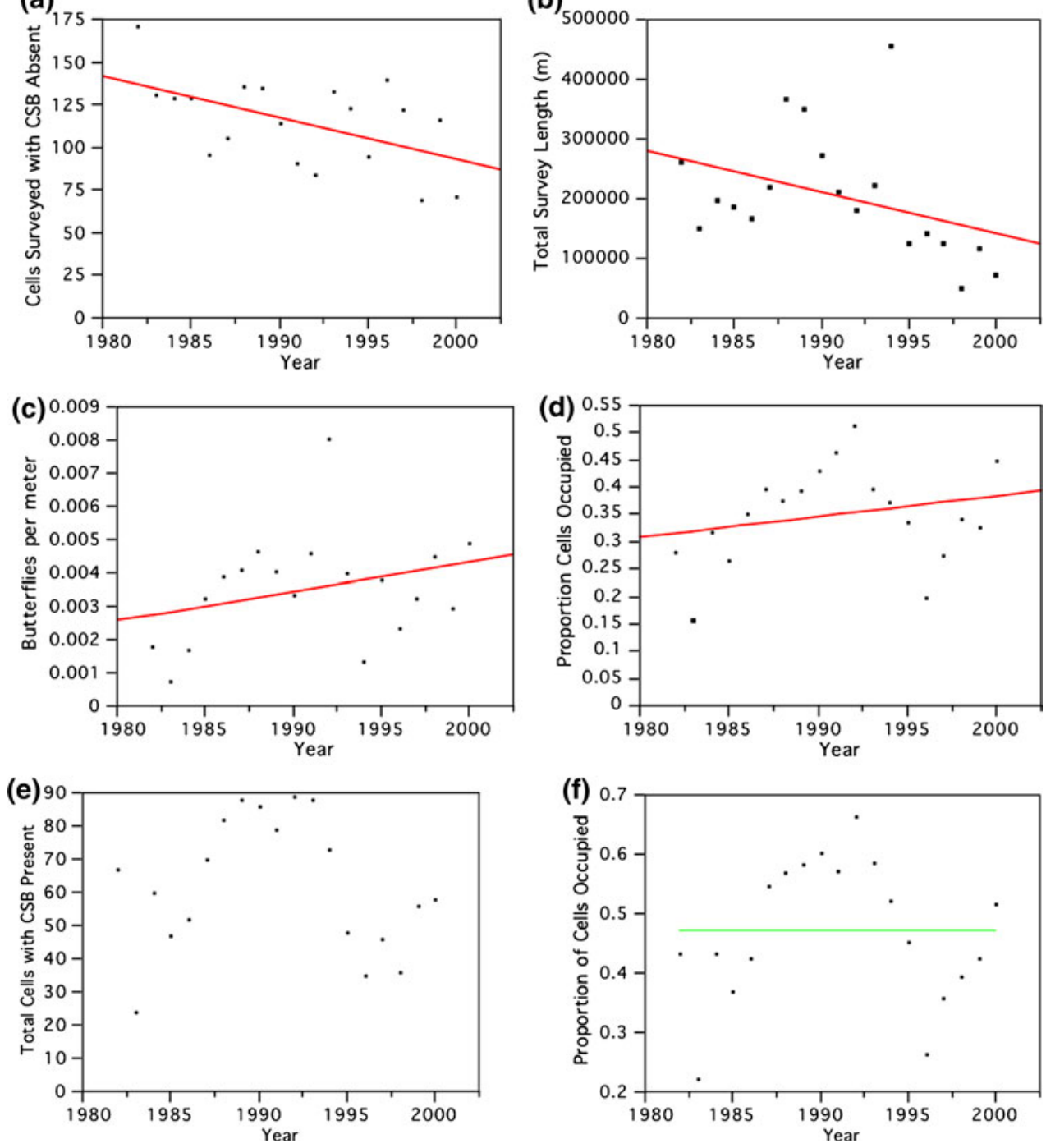

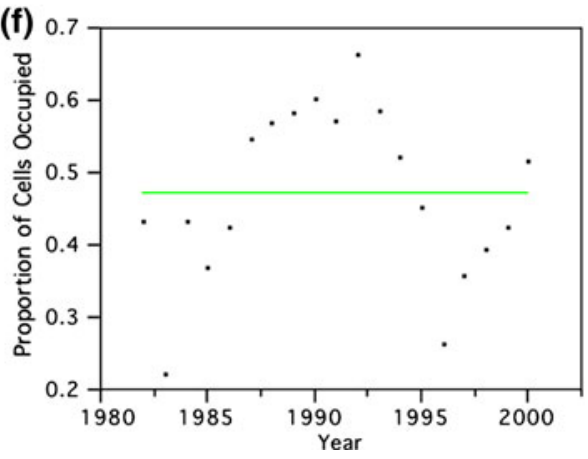

butterfly, and 165 cells that were occupied at least once by Callippe silverspot. Figure 5 depicts the cells for each species that were surveyed at least 10 years with each species present at least once, showing the proportion of years the butterfly was present. It also depicts cells where a trend during the study period was detected $(P<0.20)$. These results are based on occupancy for years surveyed, and so do not represent differences in survey frequency over time.

The cells with trends $(P<0.20)$, including those surveyed fewer than 10 years, were evenly split for mission blue butterfly (40 positive, 40 negative, with 2 cells occupied every year surveyed), and for Callippe silverspot (14 positive, 15 negative, with 6 cells occupied every year surveyed) (Fig. 6). The most stable cells for both species are concentrated on the northeast ridge, but this is also the location with a far greater proportion of negative trending cells. For Callippe silverspot, the northern half of the study area (cell numbers $<150$ ) contains 11 of 15 negative trending cells $(73 \%)$ but only 5 of 14 positive trending cells $(36 \%)$. A similar, but less dramatic pattern is seen for mission blue butterfly.

The cells with positive and negative trends were spatially clustered with other cells with similar trends. For mission blue butterfly, the ratio of positive to negative trends in surrounding cells was significantly greater for positive cells (of those cells with trends, $78 \%$ were positive) than for negative cells (of those cells with trends, $32 \%$ were positive; $P<0.0001$ ). For Callipe silverspot the same clustering occurred with $50 \%$ of surrounding trends positive for positive trending cells and $17 \%$ of surrounding trends positive for negative cells $(P<0.05)$.

Survey data provided adequate information to observe the importance of topographic relief to the two species (Fig. 4). For mission blue butterfly, the proportion of male butterflies seen within ridgeline areas $(68.9 \%)$ was extremely close to the proportion of males recorded in the whole population $(68.3 \%)$, and the same was true for females 

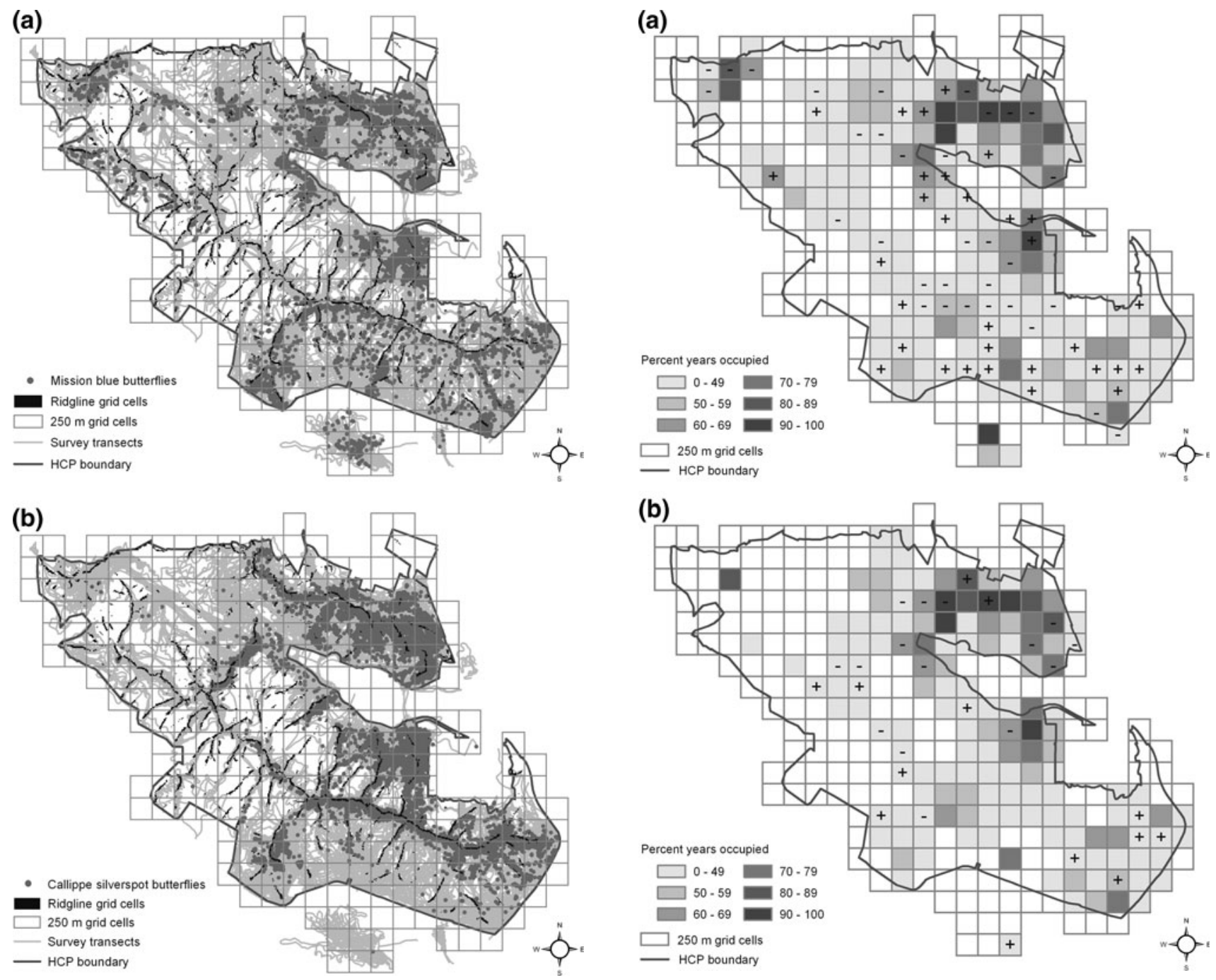

Fig. 4 Distribution of surveys and observations of mission blue butterfly (a) and Callippe silverspot butterfly (b) relative to ridgelines, 1982-2000

(26.1 vs. $26.5 \%$ ). For Callippe silverspot butterfly, males were in slightly greater proportion within the 25 -m buffer zones (41.2 vs. $37.8 \%)$ while females were present in slightly lower proportion than observed in the population (34.6 vs. 40.6\%). The percentage of Callippe silverspots of unknown sex was greater within ridgeline buffers than in the population as a whole (24.2 vs. $21.4 \%)$. These results are consistent with the observation that male Callippe silverspots use hilltops somewhat more than females.

\section{Discussion and conclusions}

The wandering transects violate most tenets of survey design. It is "convenience sampling" (Anderson 2001), providing no replication for comparison. This does not

Fig. 5 Status and trends of mission blue butterfly (a) and Callippe silverspot butterfly (b) at San Bruno Mountain. Percentage of years occupied is depicted for all cells surveyed for 10 or more years 1982 2000. Trends in occupancy $(P<0.20)$ determined by a logistic regression are indicated with + and - symbols in cells surveyed $>10$ years

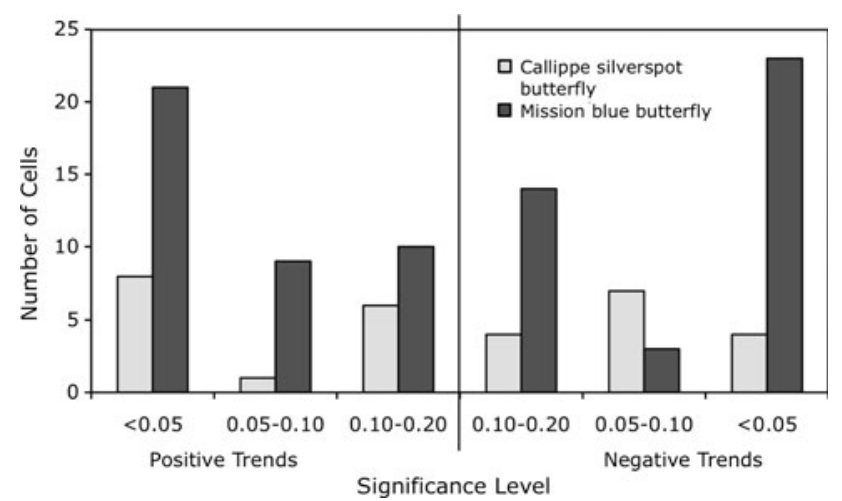

Fig. 6 Significance of trends in presence by cell for Callippe silverspot butterfly and mission blue butterfly 
suggest that the surveys were easy to complete-to the contrary, fieldwork on San Bruno Mountain is notoriously difficult and physically taxing. Rather, the design was a compromise between budget constraints and the amount of habitat area that needed to be covered. It was opportunistic rather than pre-structured, making it haphazard rather than random. Ample scientific literature was available at the time that the survey technique was designed to indicate the value of replication in the form of fixed, repeated transects (Pollard 1977; Pollard et al. 1975). Failure to apply such methods, or to develop a statistically rigorous sampling scheme, reduced the scientific value of the monitoring program. The lack of regularly repeated transects also hampers the application of subsequent techniques to estimate population size and other flight period characteristics (Mattoni et al. 2001; Zonneveld 1991).

Although the wandering surveys were deficient as a technique to gather data about butterflies from which statistical inferences can be made, they have had other benefits for those managing the natural resources at San Bruno Mountain, such as detection of invasive plants and directing management to protect butterfly habitat over a wide range of the Mountain. The value of this information is significant for protecting the habitat of the endangered species in perpetuity, which is the primary purpose of the San Bruno Mountain Habitat Conservation Plan. The purpose of this analysis, however, is to evaluate what information can be gained from the wandering transect surveys. Notwithstanding the deficiencies in survey design, sufficient information can be gained from the surveys to describe, however imperfectly, the distribution of the two butterfly species over time. Some researchers believe that survey data that lacks an estimate of search efficiency is useless for scientific analysis (Anderson 2001, 2003), but we do not subscribe to this view. The assumptions that we have made, most importantly that a survey length of $250 \mathrm{~m}$ within cells is sufficient to detect the butterflies if present, provide a conservative analysis of the situation. As discussed above, false negatives are possible, but false positives will be very rare. By switching the emphasis from abundance to occupancy, the effects of search efficiency on the results are diminished, but not eliminated. The analysis does not allow inference to cells that were not surveyed. In contrast, had the survey routes been chosen randomly, and repeated, inference could have been drawn about areas not surveyed.

For the period 1982-2000 the distribution of Callippe silverspot butterfly and mission blue butterfly in those areas surveyed at San Bruno Mountain was stable. The distribution of the population experienced changes as certain areas were colonized (or were more regularly occupied) and others exhibited trends toward local extinction.

While information relevant to the management and conservation of these species has been extracted here from the wandering transects, it is evident that the survey methodology can be improved. This analysis of the survey data has, however, yielded sufficient information to identify areas in need of management action, as well as those areas important to the survival of these two listed butterfly species.

The approach described here was devised to extract data from a sampling scheme that was not directly suited to trend analysis. Our focus on geographic distribution rather than abundance may be both applicable and useful for species monitoring schemes that are closely tied to changing habitats. In this instance, abundance of insect species that are tied in part to weather and climate variables (Weiss and Murphy 1990) may be less important to monitoring objectives than is the geographic distribution of the species. Because more butterflies are, all other things being equal, more detectible, abundance and geographic extent are correlated in surveys of butterflies (Longcore 2007). In this manner analysis of geographic extent incorporates both proxy information about overall population size and important information about changing distribution that will be useful to land managers.

This approach adds a geographic dimension to the monitoring schemes for endangered butterfly species proposed by Haddad et al. (2008) and Nowicki et al. (2008). Haddad et al. (2008) presented techniques to determine population parameters for the purpose of undertaking population viability analysis and concluded that a combination of transect and mark-recapture sampling would generate the most accurate results at least cost and harm to the butterflies. Nowicki et al. (2008) addressed efforts to define butterfly distribution and concluded that they must be improved by incorporation of statistical correctors for detectability (MacKenzie et al. 2002, 2003).

For our purposes, calculation of detection probabilities was not possible, but we note that Pellet's (2008) estimates of detectability of four butterflies at nearby Jasper Ridge indicate that false absences diminish rapidly with number of visits, with fewer than five visits necessary to reduce that rate to $<5 \%$. This result is consistent with calculations based on the characteristic abundance curve of butterflies (Zonneveld et al. 2003). Our $250 \mathrm{~m}$ per cell cut-off to count a cell as surveyed allows for single visits to be counted. A survey scheme of presence that was designed for implementation would require multiple visits during a flight season (Zonneveld et al. 2003).

Many of the significant trends in occupation for both Callippe silverspot and mission blue butterfly were located in cells that were occupied fewer than $50 \%$ of the times surveyed. These trends can be caused by a single year or two of presence at the end of the survey period for a positive trend or at the beginning for a negative trend. While interesting if connected to known changes in habitat 
conditions, they are of less interest to an assessment of the overall health of the population. Of considerably more interest are those cells where the butterfly was located for a significant proportion of years surveyed $(>70 \%)$. For Callippe silverspot, five cells with greater than $70 \%$ occupancy show negative trends, all of which are found in the northern portion of the study area. In comparison, only two cells in this northern region showed positive trends. Mission blue butterfly also exhibited negative trends in nine cells that were occupied $>70 \%$ of the surveys. These include two cells in the northwest, six in the northeast and one in the southern portion of the site.

The Northeast Ridge appears to be an important location for both butterflies, but especially Callippe silverspot. The edges of this area have shown negative trends, namely the slopes west of the Brisbane Industrial Park, the eastern Saddle and the eastern edge of the Northeast Ridge. The cell-by-cell trend analysis similarly reveals areas of concern for mission blue butterfly. The slopes west of the Brisbane Industrial Park, the northern edge of the Northeast Ridge and Guadalupe Canyon Parkway, and the northwestern corner of the Mountain exhibits negative trends. In contrast, several positive trending cells are found for both species on the south slope and southeast ridge where the majority of the habitat for both species is located.

An analysis of the vegetation composition over time within the negative trending cells revealed that coastal scrub succession and a corresponding loss of grassland habitat is likely the primary cause for the observed declines in butterfly occupancy (Fig. 7). Coastal scrub refers to native brush stands on San Bruno Mountain that consist of coyotebrush (Baccharis pilularis), poison oak (Toxicodendron diversilobum), California coffeeberry (Rhamnus

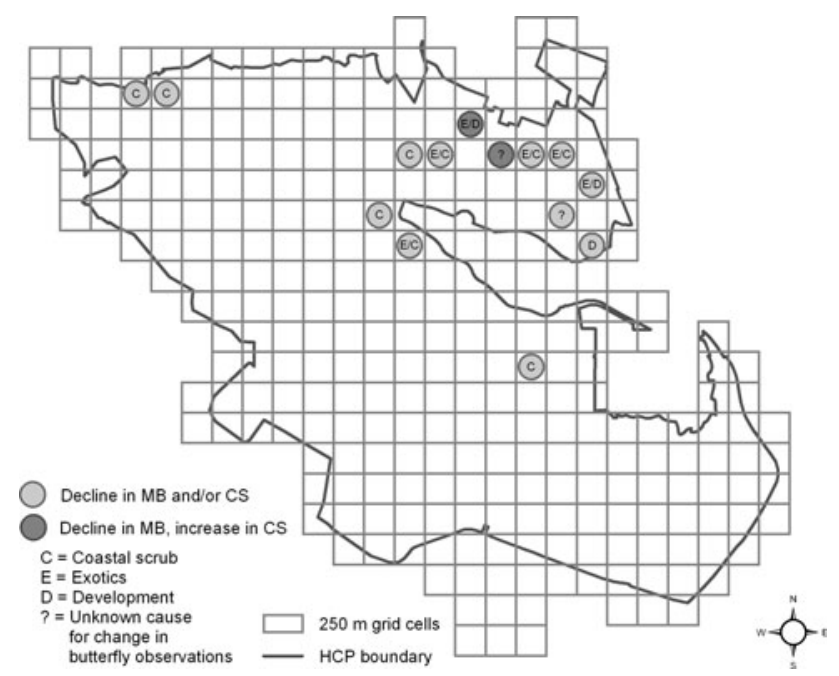

Fig. 7 Observed habitat changes within cells with $>70 \%$ occupancy and significant declining trends for mission blue butterfly and Callippe silverspot butterfly californica), California blackberry (Rubus ursinus), California sagebrush (Artemisia californica), sticky monkey flower (Mimulus aurantiacus), lizard tail (Eriophyllum staechadifolium), and blueblossom (Ceanothus thyrsiflorus), among others. Stands vary by species due to slope and exposure. Mapping of vegetation types on San Bruno Mountain was conducted in 2007 by TRA Environmental Sciences by digitizing and field checking vegetation types using 1-m pixel resolution 2004 orthophotography (TRA Environmental Sciences 2008). This analysis revealed that over the period of 1982-2004, 49 ha of grassland had converted to coastal scrub vegetation (TRA Environmental Sciences 2008). Review of this data as well as terrestrial and aerial imagery of the Mountain from 1982 to 2004, and field inspection of each of the cells with recorded trends and $>70 \%$ occupancy, revealed that most of the declining cells were located in grassland areas that had converted to coastal scrub vegetation over the past 22 years (Fig. 7). Specifically, cells with declining trends had either (1) a large increase in aerial extent of coastal scrub vegetation (cells 24, 25, 70, 107, 190); or (2) a large increase in aerial extent of both coastal scrub and invasive species (i.e. exotics) (cells 71, 74, 75, 125). Only two cells with a declining trend were identified and coastal scrub had not increased (cells 54 and 131). A review of the positive trending cells with $>70 \%$ occupancy revealed only minor changes in vegetation, and grassland remained as the dominant $(>50 \%)$ vegetation type. Of the fourteen cells identified as showing significant declines for either mission blue or Callippe silverspot, nine cells had transitioned from grassland to coastal scrub as the dominant $(>50 \%)$ vegetation type. These areas are located on north facing slopes known as Buckeye Canyon, the Saddle, Hill West of Quarry, Northeast Ridge (western portion) and Wax Myrtle Ravine. By the mid-1990s, transect routes through each of these areas had to be eliminated or rerouted due to the increased density of coastal scrub vegetation.

The loss of approximately 49 ha of grassland habitat corresponds to a rate of conversion from grassland to scrub of 2.2 ha per year (TRA Environmental Sciences 2008). Most of this conversion has occurred on lower elevation, north facing slopes (Fig. 8). The conversion of grassland to 'brush' on San Bruno Mountain was also calculated in 1982, when it was estimated that approximately 541 acres (219 ha) of grasslands had converted to brush between 1932 and 1981 (Thomas Reid Associates 1982b). This corresponds to a rate of conversion of 4.4 ha per year.

Management of the HCP area for the endangered butterflies for the past two and a half decades has focused almost exclusively on the control of invasive species. The most consistent treatment has been conducted on woody invasive brush and trees such as gorse (Ulex europaea), French broom (Genista monspessulana), Portuguese broom (Cytisus 

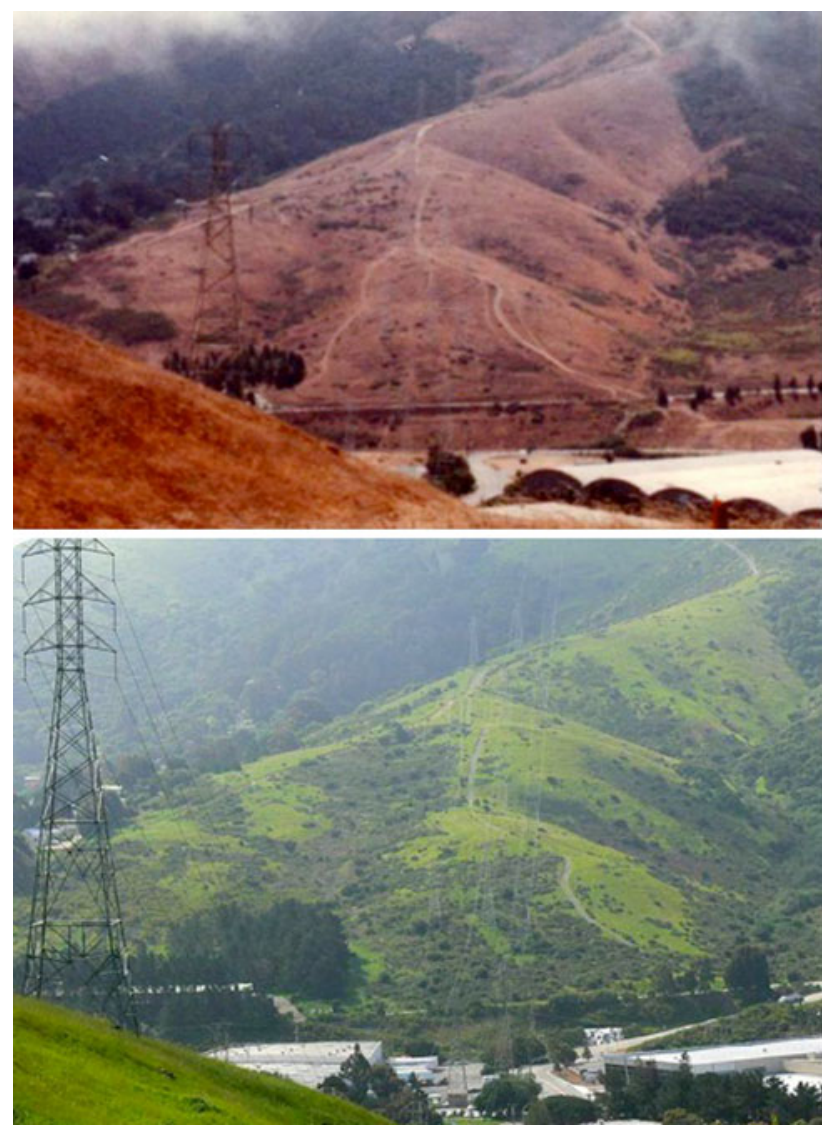

Fig. 8 View of Buckeye Canyon and eastern ridge in 1986 (top) and 2006 (bottom). Coastal scrub vegetation, and to a lesser extent invasive brush, have increased substantially over the 20 year period. Photos by TRA Environmental Sciences, Inc

striatus), and blue gum (Eucalyptus globulus) (TRA Environmental Sciences 2008). These efforts have either contained the spread or significantly reduced the extent of these species (gorse by approximately $80 \%$ and eucalyptus by approximately $30 \%$ ) during that period (TRA Environmental Sciences 2008). However, based on the observed declining trends of butterfly occupancy and vegetative changes on north facing slopes, management needs to also address native coastal scrub succession to protect grassland habitat and the butterflies of concern from continued habitat loss.

Invasions of brush into grasslands have been documented in other grassland habitats in the San Francisco Bay area over the past 30-40 years (McBride 1974; Williams et al. 1987), and the process may be occurring as a result of grazing exclusion as well as from higher spring rainfall (Williams et al. 1987). The San Bruno Mountain habitat managers have been aware of the coastal scrub succession problem on the Mountain as it was identified in the HCP in 1982 and of the need to implement management tools such as mechanical thinning, grazing, or burning to counteract the process of succession (Thomas Reid Associates 1982b).
Taking actions to provide disturbance and reverse or slow the process of coastal scrub succession has been difficult. It has been hampered by (a) the high cost and lack of funding to implement both invasive species control and native brush control programs, (b) political opposition to grazing, and (c) human safety concerns over conducting controlled burns near urban areas. While there has been a high level of concern over reports that the HCP habitat managers have not adequately controlled invasive species on San Bruno Mountain (Sigg 1993), there has far less concern over the threat to endangered butterfly habitat from native coastal scrub succession. The perception of native plants as 'good' and nonnative plants as 'bad' is a recurring theme in the current environmental public consciousness, but applying this as a uniform strategy for habitat management may not address actual threats to habitat for these butterfly species. The butterflies' grassland habitat can be as easily overtaken by native coastal scrub as it can by invasive species and actual threats to habitat areas need to be addressed on a local level based on slope, microclimate, surrounding vegetation and other factors.

Coastal scrub vegetation only becomes a threat to the butterflies' grassland habitat on San Bruno Mountain when it reaches a high enough density to negatively affect butterfly host and nectar resources, or the ability of the butterflies to locate those resources. This typically occurs in areas with more moisture and less solar exposure such as north facing slopes. Moderate densities of coastal scrub within the grasslands of San Bruno Mountain provide important resources for the endangered butterflies such as additional nectar sources, perching sites and partial shading and soil moisture retention that often benefits the butterflies' host and nectar plants, especially Viola pedunculata (TRA Environmental Sciences 2008). For these reasons, management of coastal scrub succession should be focused on brush thinning and control rather than eradication.

The importance of maintaining habitat on north facing exposures has been illustrated for the Bay checkerspot butterfly (Euphydryas editha bayensis), a threatened species also found in the San Francisco Bay area that utilizes grassland habitat (Weiss et al. 1988). In the northern hemisphere, north facing slopes are typically cooler and wetter than south facing slopes, with significant differences in vegetation composition as a result. The distribution of larvae of the Bay checkerspot changes substantially from year to year across slopes, reflecting spatial patterns of prediapause survivorship (Weiss et al. 1988). Larvae from egg masses laid on cooler slopes were found to nearly always have a better chance to reach diapause than those laid concurrently on warmer slopes, because of the later onset of plant senescence on cooler slopes. Cool slopes are high quality habitat for prediapause larvae, and become 
better relative to warmer slopes as the flight season progresses (Weiss et al. 1988).

In general, the protection and management of habitat on a variety of slope exposures under different microclimatic conditions is a logical strategy to provide adequate habitat to support population shifts of grassland endemic butterfly species in response to climatic fluctuations. Populations inhabiting topographically uniform areas without cool slopes that can act as refuges are unable to undergo thermal retreat and are more vulnerable to extinction that populations in more diverse habitat patches (Weiss and Murphy 1990). North facing slopes, and other cooler exposures are likely to become even more important as refugia for grassland endemic butterflies if global climate trends continue as expected. These findings suggest that the mission blue and the Callippe silverspot populations on San Bruno Mountain were stable during the study period, but loss of grasslands to scrub succession in some areas is a cause for concern. The implementation of management programs to control native coastal scrub is needed to protect the habitat of the mission blue and Callippe silverspot butterflies especially on lower north-facing slopes, and other areas prone to coastal scrub succession on San Bruno Mountain.

Acknowledgments Research reported in this manuscript was supported by the County of San Mateo. PK and EP both worked at TRA Environmental Sciences; PK was the habitat manager on San Bruno Mountain from 1995 to 2007 and EP was associate biologist from 2000 to 2003.

Open Access This article is distributed under the terms of the Creative Commons Attribution Noncommercial License which permits any noncommercial use, distribution, and reproduction in any medium, provided the original author(s) and source are credited.

\section{References}

Anderson DR (2001) The need to get the basics right in wildlife field studies. Wildl Soc Bull 29:1294-1297

Anderson DR (2003) Response to Engeman: index values rarely constitute reliable information. Wildl Soc Bull 31:288-291

Arnold RA (1981) Distribution, life history, and status of three California lepidoptera proposed as endangered or threatened species. Final report for contract \#S-1620. Inland Fisheries Branch, California Department of Fish and Game, Sacramento, California

Arnold RA (1983) Ecological studies of six endangered butterflies (Lepidoptera, Lycaenidae): island biogeography, patch dynamics, and the design of habitat preserves. Univ Calif Publ Entomol 99:1-161

Beatley T (1994) Habitat conservation planning: endangered species and urban growth. University of Texas Press, Austin

Buckland ST, Anderson DR, Burnham KP, Laake JL (1993) Distance sampling: estimating abundance of biological populations. Chapman \& Hall, London

Dennis RLH (2001) Progressive bias in species status is symptomatic of fine-grained mapping units subject to repeated sampling. Biodivers Conserv 10:483-494. doi:10.1023/A:1016602309983
Dennis RLH, Sparks TH (2006) When is a habitat not a habitat? Dramatic resource use changes under differing weather conditions for the butterfly Plebejus argus. Biol Conserv 129:291301. doi:10.1016/j.biocon.2005.10.043

Dennis RLH, Shreeve TG, Van Dyck H (2003) Towards a functional resource-based concept for habitat: a butterfly biology viewpoint. Oikos 102:417-426

Dennis RLH, Shreeve TG, Isaac NJB, Roy DB, Hardy PB, Fox R, Asher J (2006a) The effects of visual apparency on bias in butterfly recording and mointoring. Biol Conserv 128:486-492. doi:10.1016/j.biocon.2005.10.015

Dennis RLH, Shreeve TG, Van Dyck H (2006b) Habitats and resources: the need for a resource-based definition to conserve butterflies. Biodivers Conserv 15:1943-1966. doi:10.1007/s10531-0054314-3

Downey JC (1957) Infraspecific variation and evolution in populations of Plebejus icarioides (Bdv.). Ph.D. Dissertation, Department of Zoology, University of California, Davis, California, pp 179

Gall LF (1985) Measuring the size of Lepidopteran populations. J Res Lepid 24:97-116

Guppy CS, Shepard JH (2001) Butterflies of British Columbia including western Alberta, southern Yukon, the Alaska panhandle, Washington, northern Oregon, northern Idaho, northwestern Montana. University of British Columbia Press, Vancouver, British Columbia, Canada

Haddad NM, Hudgens B, Damiani C, Gross K, Kuefler D, Pollock K (2008) Determining optimal population monitoring for rare butterflies. Conserv Biol 22:929-940. doi:10.1111/j.1523-1739. 2008.00932.x

Hanski I (1999) Metapopulation dynamics. Oxford University Press, Oxford

Harker RJ, Shreeve TG (2008) How accurate are single site transect data for monitoring butterfly trends? Spatial and temporal issues identified in monitoring Lasiommata megera. J Insect Conserv 12:125-133. doi:10.1007/s10841-007-9068-7

Longcore T (2007) Final report for 2007 Palos Verdes blue butterfly adult surveys on Defense Fuel Support Point, San Pedro, California. Defense Logistics Agency Agreement \#N68711-07LT-R0011. The Urban Wildlands Group, Los Angeles

MacKenzie DI, Nichols JD, Lachman GB, Droege S, Royle JA, Langtimm CA (2002) Estimating site occupancy rates when detection probabilities are less than one. Ecology 83:2248-2255. doi:10.1890/0012-9658(2002)083[2248:ESORWD]2.0.CO;2

MacKenzie DI, Nichols JD, Hines JE, Knutson MG, Franklin AD (2003) Estimating site occupancy, colonization and local extinction when a species is detected imperfectly. Ecology 84: 2200-2207. doi:10.1890/02-3090

Mattoni R, Longcore T, Zonneveld C, Novotny V (2001) Analysis of transect counts to monitor population size in endangered insects: the case of the El Segundo blue butterfly, Euphilotes bernardino allyni. J Insect Conserv 5:197-206. doi:10.1023/A:101798 7929824

Mattoon SO, Davis RD, Spencer OD (1971) Rearing techniques for species of Speyeria (Nymphalidae). J Lepid Soc 25:247-256

McBride JR (1974) Plant succession in the Berkeley Hills, California. Madroño 22:317-380

Nagal HG, Nightengale T, Dankert N (1991) Regal fritillary butterfly population estimation and natural history on Rowe Sanctuary, Nebraska [USA]. Prairie Nat 23:145-152

Nowicki P, Settele J, Henry P-Y, Woyciechowski M (2008) Butterfly monitoring methods: the ideal and the real world. Isr J Ecol Evol 54:69-88. doi:10.1560/IJEE.54.1.69

Pellet J (2008) Seasonal variation in detectability of butterflies surveyed with Pollard walks. J Insect Conserv 12:155-162. doi: $10.1007 / \mathrm{s} 10841-007-9075-8$ 
Pollard E (1977) A method for assessing change in the abundance of butterflies. Biol Conserv 12:115-132. doi:10.1016/0006-3207 (77) $90065-9$

Pollard E (1988) Temperature, rainfall and butterfly numbers. J Appl Ecol 25:819-828

Pollard E, Yates TJ (1993) Monitoring butterflies for ecology and conservation; The British Butterfly Monitoring Scheme. Chapman \& Hall, London

Pollard E, Elias DO, Skelton MJ, Thomas HA (1975) A method of assessing the abundance of butterflies in Monks Wood National Nature Reserve in 1973. Entomol Gaz 26:79-88

Ricketts TH (2001) The matrix matters: effective isolation in fragmented landscapes. Am Nat 158:87-99

Schultz CB, Hammond PW (2003) Using population viability analysis to develop recovery criteria for endangered insects: case study of the Fender's blue butterfly. Conserv Biol 17:13721385. doi:10.1046/j.1523-1739.2003.02141.x

Shields O (1967) Hilltopping: an ecological study of summit congregation behavior of butterflies on a southern California hill. J Res Lepid 6:69-178

Sigg J (1993) Habitat conservation on San Bruno Mountain: it isn't working. Fremontia 21:11-14

Thomas Reid Associates (1982a) Final report to San Mateo County Steering Committee for San Bruno Mountain: endangered species survey (San Bruno Mountain), biological study-19801981. Thomas Reid Associates, Palo Alto, California

Thomas Reid Associates (1982b) San Bruno Mountain Habitat Conservation Plan, Volumes I and II. San Bruno Mountain
Habitat Conservation Plan Steering Committee, County of San Mateo

Thomas Reid Associates (2000) San Bruno Mountain Habitat Conservation Plan 1999 Activities Report for Endangered Species Permit PRT 2-9818. County of San Mateo, Palo Alto, California

TRA Environmental Sciences (2008) San Bruno Mountain Habitat Management Plan 2007 (Revised March 2008). San Mateo County Parks Department, Redwood City, California

van Swaay CAM, Nowicki P, Settele J, van Strien AJ (2008) Butterfly monitoring in Europe: methods, applications and perspectives. Biodivers Conserv 17:3455-3469. doi:10.1007/s10531-008-9491-4

Weiss SB, Murphy DD (1990) Thermal microenvironments and the restoration of rare butterfly habitat. In: Berger JJ (ed) Environmental restoration: science and strategies for restoring the earth. Island Press, Washington

Weiss SB, Murphy DD, White RR (1988) Sun, slope, and butterflies: topographic determinants of habitat quality for Euphydryas editha. Ecology 69:1486-1496

Williams KS, Hobbs RJ, Hamburg SP (1987) Invasion of an annual grassland in northern California by Baccharis pilularis ssp. consanguinea. Oecologia 72:461-465

Zonneveld C (1991) Estimating death rates from transect counts. Ecol Entomol 16:115-121. doi:10.1111/j.1365-2311.1991.tb00198.x

Zonneveld C, Longcore T, Mulder C (2003) Optimal schemes to detect presence of insect species. Conserv Biol 17:476-487. doi: 10.1046/j.1523-1739.2003.01516.x 